\title{
RELATIONSHIPS OF PYRUVATE AND LACTATE DURING ANAEROBIC METABOLISM. I. EFFECTS OF INFUSION OF PYRUVATE OR GLUCOSE AND OF HYPERVENTILATION ${ }^{1}$
}

\author{
By WILLIAM E. HUCKABEE \\ (From the Robert Dawen Evans Memorial, Massachusetts Memorial Hospitals, and the \\ Department of Medicine, Boston University School of Medicine, Boston, Mass.)
}

(Submitted for publication August 3, 1957 ; accepted September 26, 1957)

When the supply of oxygen to the interior of living cells is reduced to a rate insufficient for their current metabolic needs for oxygen, then various cellular oxidation-reduction systems must shift toward a more reduced state. Thus, as the oxygen tension falls the "oxidation potential" ("E $\mathrm{E}_{\mathrm{h}}$ ") decreases $(1,2)$, (the rate of decrease being a complex and variable function of $\mathrm{Po}_{2}$ and also of the rate of energy utilization), and the various redox systems shift toward their reduced forms in a sequence determined by their inherent redox characteristics (1), cytochrome oxidase, the cytochromes and their dependent systems, flavoproteins and diphosphopyridine nucleotide (DPN). The lowest potential in the "carrier" system is that of DPN, which is the final electron donator and functions also in the "metabolic" oxidative systems; the rates of the oxidations of energy metabolism are not affected until DPN is affected.

When the oxidative potential in the hypoxic cell has diminished to the level of the potentials of the "metabolic" systems, the first of these DPN-coupled systems to become reversed will be the one of potential closest to that of DPN : $\mathrm{DPNH}_{2}$, the lactic dehydrogenase (LDH) system.

1) Pyruvate $+\mathrm{DPNH}_{2} \stackrel{\mathrm{LDH}}{\rightleftarrows}$ Lactate $+\mathrm{DPN}$

The fact that this system should shift toward the reduced state at the same time as the final transport system (DPN) appears to be an important arrangement of potentials from the point of view of the continuance of cell life during hypoxia. This is because the end-product of reduction in the LDH system is lactate, which has no other function in metabolism. All the other metabolic redox systems operate in series, so that the products of one system become the substrates of another, or several other, systems; if oxidation in

1 Aided in part by a grant from the American Heart Association. one of these systems were to stop or slow down, the whole process of energy metabolism would be affected. The LDH system, however, is unique in being "dead-end;" endogenous lactate does not participate in any other equilibrium or enter into any other reaction which would be affected by its accumulation in the cell. ${ }^{2}$

Lactate is not the only product of a shift to the right in the steady state depicted by equation 1 ). Oxidized DPN also is produced from reduced DPN. Under conditions of true oxygen deficiency within the cell, then, as the oxidation of $\mathrm{DPNH}_{2}$ by molecular oxygen through the carrier system falls off, oxidation of $\mathrm{DPNH}_{2}$ by the $\mathrm{LDH}$ system takes up. If this substitution for oxygen could occur at a sufficient rate, the oxidative potential of the cell medium would fall no further, and the remainder of the oxidations of energy metabolism could therefore continue, and life would be sustained. If the systems at any other level of potential had a significant poising effect, the fall of " $E_{h}$ " might be checked (1), but in those cells which have been studied this usually does not appear to be the case $(1,2)$, " $E_{h}$ " falling to about -0.180 , that of $\mathrm{LDH}$.

It is important to emphasize that the situations envisaged by this reasoning do not include 1 ) complete, or even nearly complete, absence of oxygen (which would halt the succinic system), or 2) the possible toxic effects of unlimited lactate and acid accumulation. It is true that most mammalian tissues cease to function or die in the total absence of oxygen. However, the survival of animals and human patients during a great variety of lesser hypoxic states, especially during cardiopulmonary

2 This assertion is not dependent solely on the failure to discover any other lactate reaction in mammalian tissues up to the present time (3), but is confirmed by the close parallelism of specific activities of lactate and pyruvate from living tissue following exhibition of isotope-tagged pyruvate $(4,5)$. 
disease, may be attributable to the existence of "anaerobic metabolism" such as that described above. It has been known for many years that lactate is produced in hypoxic states $(6,7)$ in intact animals.

If the rate at which this anaerobic metabolism occurs in intact animals during a particular period could be estimated, it would be possible to deduce in essential metabolic terms the extent to which oxygen supply was inadequate to meet tissue demands. Hill, Long, and Lupton (8), Jervell (9), and others have attempted to make such estimates from the total amount of lactate produced. However, only after their work was published was the $\mathrm{LDH}$ system described as an equilibrium as shown in equation 1). It is obvious from this equation that it is not theoretically possible to use lactate alone for estimating changes in DPN : $\mathrm{DPNH}_{2}$ unless pyruvate could be assumed to remain unchanged at all times. Otherwise, one of the four factors in the system will have been omitted from consideration, and some inexplicable changes in lactate production might be expected to occur. It is not surprising, therefore, to find that a number of conditions other than the state of oxidation of DPN can lead to lactate production in the absence of hypoxia (10-13). Such nonhypoxic lactate production precludes the use of lactate alone as a quantitative estimate of the anaerobic metabolism brought on by hypoxia.

If all the elements of equation 1) are properly used, on the other hand, an exact understanding of the relationship between metabolism and oxygen supply should be possible. If equation 1) is written in its mass action form, the following expression is obtained:

\section{2) $[$ Lactate $]=[$ Pyruvate $] \times \mathrm{K} \frac{\left[\mathrm{DPNH}_{2}\right]}{[\mathrm{DPN}]}$}

This form clearly illustrates the dependence of lactate production upon two separate factors : pyruvate and $\mathrm{K} \frac{\left[\mathrm{DPNH}_{2}\right]}{[\mathrm{DPN}]}$, or the adequacy of oxygen supply. It may, therefore, be suggested on a theoretical basis that all instances of lactate production by tissues can be divided into three types: lactate production due to $(a)$ inadequacy of oxygen supply relative to metabolic needs, i.e., change in the factor $\mathrm{K} \frac{\left[\mathrm{DPNH}_{2}\right]}{[\mathrm{DPN}]}$ alone; $(b)$ change in pyru- vate production alone; and $(c)$ changes in both factors simultaneously.

For all practical purposes $(a)$ does not seem to occur, in our experience, in dogs, goats or human patients, although an occasional experiment may approximate it, presumably merely as one form of group (c). It becomes important, however, to distinguish lactate changes due to $(b)$ from those due to $(c)$.

This has been done by studying a tissue or an animal at two points in time with respect to the quantities of pyruvate and lactate present. An expected lactate value for an experimental period $t_{n}$ is calculated from the figure for $\mathrm{K} \frac{\left[\mathrm{DPNH}_{2}\right]}{[\mathrm{DPN}]}$ obtained at a control time, $t_{0}$, plus the observed pyruvate change, $P_{n}-P_{0}$. In other words, it is initially assumed for the purpose of determining the theoretical change in lactate resulting only from the change in pyruvate that no hypoxia occurred between $t_{0}$ and $t_{n}$. If the amount of change in lactate actually observed is equal to this, then it is concluded that all the lactate produced is accounted for simply by the change in pyruvate. If the amount of change in lactate actually observed exceeds this predicted value, $\widehat{\Delta \mathrm{L}}$, then the assumption of no hypoxia was incorrect; but the "excess lactate" obtained by difference $\left[\left(\mathrm{L}_{\mathbf{n}}-\right.\right.$ $\left.\left.L_{0}\right)-\widehat{\Delta L}\right]$ can be present only because a change in $\mathrm{K} \frac{\left[\mathrm{DPNH}_{2}\right]}{[\mathrm{DPN}]}$ has occurred, and serves as a measure of this change. The final equation for calculating this theoretical fraction of the total concentration change, the "excess lactate" or XL, is derived in the appendix and is as follows:

3) $X L=\left(L_{n}-L_{o}\right)-\left(P_{n}-P_{o}\right)\left(L_{o} / P_{o}\right)$

where $L_{n}$ and $L_{0}$ are experimental and control lactate concentrations, $P_{n}$ and $P_{0}$ experimental and control concentrations of pyruvate, respectively.

In order to examine the pertinence of this theoretical quantity, XL, to body physiology, human subjects and animals were subjected to a group of conditions which were known to produce lactate accumulation without, insofar as it can be determined, any effect on oxygen supply. The simplest and most direct of these was infusion of pyruvate. Infusion of glucose represents a similar stimulus but one which more nearly imitates physiologic changes which may take place 


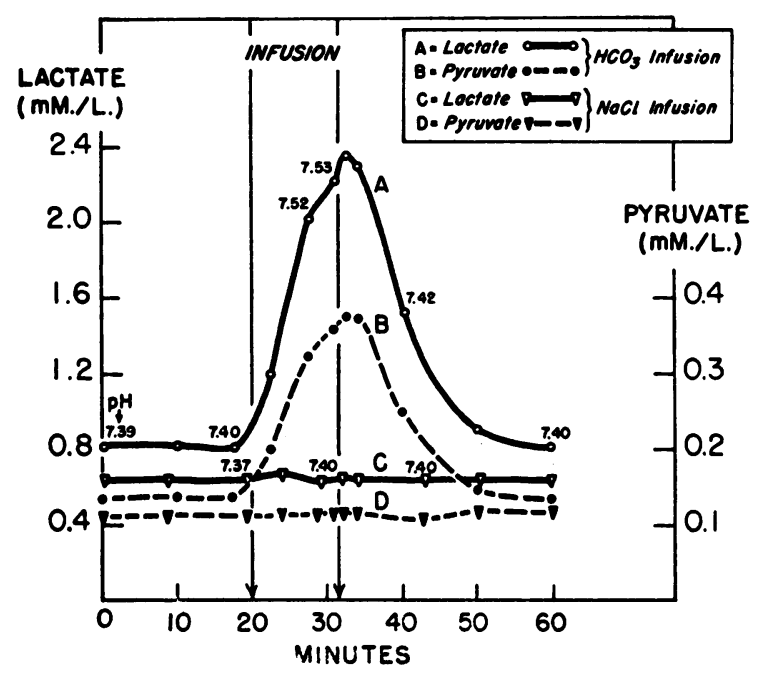

Fig. 1. Typical Changes in Blood lactate and Pyruvate in a Dog During Intravenous Infusion of Sodium Bicarbonate Solution (Curves A and B) and Sodium Chloride Solution (Curves C and D)

The effect of bicarbonate is essentially the same as that of hyperventilation or the infusion of sodium pyruvate. No change occurred in arterial or mixed venous blood oxygen saturations. Excess lactate values zero.

naturally. The third, hyperventilation and alkalosis, was studied both because it produces the most striking lactate accumulations and because $\mathrm{pH}$ changes are complicating factors in most studies of hypoxia.

\section{METHODS}

Blood samples from human subjects were collected as previously described (14). Briefly, an indwelling arterial needle was inserted into a brachial artery under local anesthesia, and blood was allowed to flow rapidly through a short length of plastic tubing directly into a weighed tube of ice cold 10 per cent trichloracetic acid in $0.5 \mathrm{~N} \mathrm{HCl}$. Lactate and pyruvate analyses were carried out in triplicate as previously described (14); each recorded figure represents the mean of all analyses on two blood samples collected in rapid succession. Reproducibility of successively drawn samples during a steady state was about 0.5 per cent for lactate and 1.0 per cent for pyruvate. Blood samples were collected from dogs in the same manner except that each arterial sample was accompanied by a similarly collected sample of mixed venous blood from a wide-bore brass cannula inserted through the jugular vein into the right ventricle of the heart. Blood water content was determined with each sample and all concentrations are given in millimoles per liter of blood water. Blood oxygen determinations were carried out either manometrically in the Van Slyke apparatus, or spectrophotometrically (15). The $\mathrm{pH}$ of blood samples was determined with a glass electrode at $37^{\circ} \mathrm{C}$. after collection in sodium fluoride and preservation in ice for about an hour.

Oxygen consumption rates were calculated from the minute volume of inspired air delivered from a spirometer and the oxygen, carbon dioxide, and nitrogen contents of expired air as determined with the standard Haldane apparatus. Control samples were taken after an hour of rest. Animals were anesthetized with $20 \mathrm{mg}$. chloralose per $\mathrm{Kg}$., although the present results have been duplicated in animals under pentobarbital anesthesia when arterial oxygen saturation was normal.

\section{RESULTS}

Infusing sodium pyruvate solutions having $\mathrm{pH}$ 7.0 or 7.4 led to a considerable alkalinizing effect. Such infusions had previously been given by Bueding and Goldfarb (16) and tacitly compared, presumably, with control infusions of sodium chloride. The proper control infusate, however, should be sodium bicarbonate solution $(17,18)$ which has an effect, as shown in Figure 1 (curves A and B), essentially identical with that of sodium pyruvate. From this observation it might be concluded that pyruvate infusion, in fact, has no specific effect on blood lactate, but only the effect of an alkalinizing salt. The same effects on blood pyruvate and $\mathrm{pH}$ were elicited with $0.10 \mathrm{M}$ sodium pyruvate solutions at infusion rates between 1 and $4 \mathrm{ml}$. per minute ( 0.2 to $0.4 \mathrm{mM}$ per minute) for

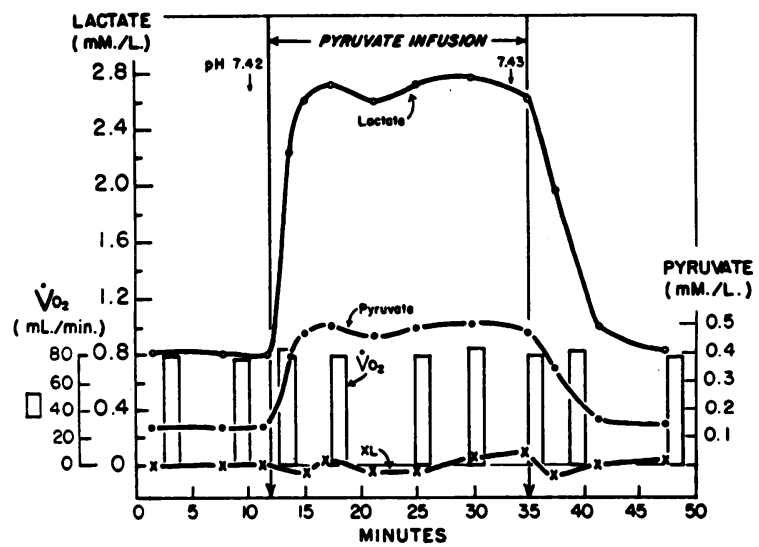

Fig. 2. Typical Effects of Infusion of Buffered 0.5 M Pyruvate Solution (pH 5.5) on Blood Lactate and Pyruvate and on Rate of Oxygen Consumption in an Anesthetized Dog

Absence of change in oxygen consumption and on oxygen saturation of arterial (96.2 per cent) and right ventricular blood (70.9 per cent) gave no evidence of hypoxia. 
TABLE I

Effect of intravenous infusion of acidic pyruvate solutions in dogs on blood lactate and pyruvate concentrations*

\begin{tabular}{|c|c|c|c|c|c|c|}
\hline Procedure & Lactate & Pyruvate & $\mathrm{XL}+$ & $\mathrm{pH}$ & $\dot{V}_{02} \dagger$ & $S \overline{\mathrm{V}}_{\mathrm{O}_{2}}^{\dagger}$ \\
\hline $\begin{array}{l}\text { Control } \\
\text { Infusion } \\
\text { Recovery }\end{array}$ & $\begin{array}{c}m M / L . \\
0.695 \\
3.788 \\
0.709\end{array}$ & $\begin{array}{l}m M / L . \\
0.120 \\
0.648 \\
0.121\end{array}$ & $\begin{array}{c}m M / L . \\
0 \\
0.033 \\
0.008\end{array}$ & $\begin{array}{l}7.41 \\
7.40 \\
7.40\end{array}$ & $\begin{array}{c}\text { ml. } / \text { min. } \\
66 \\
65 \\
65\end{array}$ & $\begin{array}{l}\% \\
74 \\
76 \\
73\end{array}$ \\
\hline $\begin{array}{l}\text { Control } \\
\text { Infusion } \\
\text { Recovery }\end{array}$ & $\begin{array}{l}0.722 \\
2.090 \\
0.730\end{array}$ & $\begin{array}{l}0.143 \\
0.410 \\
0.144\end{array}$ & $\begin{array}{c}0 \\
0.023 \\
0.003\end{array}$ & $\begin{array}{l}7.39 \\
7.41 \\
7.41\end{array}$ & $\begin{array}{l}88 \\
89 \\
90\end{array}$ & $\begin{array}{l}72 \\
75 \\
75\end{array}$ \\
\hline $\begin{array}{l}\text { Control } \\
\text { Infusion } \\
\text { Recovery }\end{array}$ & $\begin{array}{l}0.652 \\
4.920 \\
0.700\end{array}$ & $\begin{array}{l}0.125 \\
0.946 \\
0.133\end{array}$ & $\begin{array}{c}0 \\
0 \\
0.006\end{array}$ & $\begin{array}{l}7.40 \\
7.40 \\
7.38\end{array}$ & $\begin{array}{l}92 \\
90 \\
90\end{array}$ & $\begin{array}{l}75 \\
77 \\
74\end{array}$ \\
\hline $\begin{array}{l}\text { Control } \\
\text { Infusion } \\
\text { Recovery }\end{array}$ & $\begin{array}{l}0.820 \\
2.876 \\
0.815\end{array}$ & $\begin{array}{l}0.128 \\
0.453 \\
0.127\end{array}$ & $\begin{array}{l}0 \\
0 \\
0\end{array}$ & $\begin{array}{l}7.42 \\
7.39 \\
7.42\end{array}$ & $\begin{array}{l}71 \\
74 \\
73\end{array}$ & $\begin{array}{l}71 \\
74 \\
71\end{array}$ \\
\hline $\begin{array}{l}\text { Control } \\
\text { Infusion } \\
\text { Recovery }\end{array}$ & $\begin{array}{l}0.871 \\
3.720 \\
0.860\end{array}$ & $\begin{array}{l}0.142 \\
0.600 \\
0.138\end{array}$ & $\begin{array}{c}0 \\
0.039 \\
0.014\end{array}$ & $\begin{array}{l}7.38 \\
7.40 \\
7.39\end{array}$ & $\begin{array}{l}102 \\
102 \\
100\end{array}$ & $\begin{array}{l}76 \\
78 \\
74\end{array}$ \\
\hline
\end{tabular}

* Only experiments with unaltered blood pH are shown. Values marked "infusion" were obtained 5 minutes after stopping the infusion; "recovery" values were obtained 30 minutes later.

$\dagger \mathrm{XL}=$ Excess lactate.

$\mathrm{V}_{\mathrm{O}_{2}}=$ Oxygen consumption.

$\mathrm{S}_{\mathrm{V}_{2}}=$ Mixed venous blood oxygen saturation.

TABLE II

Arterial blood lactate and pyruvate concentrations 15 minutes after intravenous infusions of 10 per cent glucose solutions for 30 minutes in human subjects, and dogs anesthetized with chloralose, showing no calculated excess lactate formation $(X L)$

\begin{tabular}{lllc}
\hline $\begin{array}{l}\text { Subject } \\
\text { Procedure }\end{array}$ & Lactate & Pyruvate & $\mathrm{XL}$ \\
\hline Human & $m M / L$. & $m M / L$. & $m M / L$. \\
$\quad$ Control & & & \\
Glucose, I.V. & 0.542 & 0.132 & 0 \\
Human & 0.655 & 0.157 & 0.010 \\
Control & & & \\
Glucose, I.V. & 0.481 & 0.125 & 0 \\
Human & 0.580 & 0.149 & 0.006 \\
Control & & & \\
Glucose, I.V. & 0.511 & 0.127 & 0 \\
Human & 0.699 & 0.170 & 0.016 \\
Control & & & \\
Glucose, I.V. & 0.420 & 0.119 & 0 \\
Dog & 0.510 & 0.144 & 0 \\
Control & & & \\
Glucose, I.V. & 0.924 & 0.131 & 0 \\
Dog & 1.357 & 0.191 & 0.013 \\
Control & & & \\
Glucose, I.V. & 1.248 & 0.194 & 0.023 \\
Dog & & & \\
Control & 0.784 & 0.119 & 0 \\
Glucose, I.V. & 1.154 & 0.176 & 0 \\
\hline
\end{tabular}

periods of time from 5 to 20 minutes. The sudden single injections of very large quantities, as previously done (16), were considered difficult to interpret, so that continuous infusions were em-

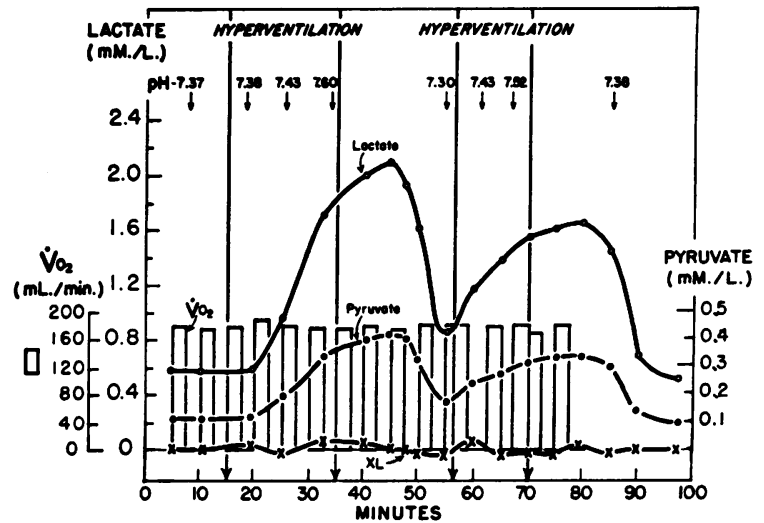

Fig. 3. Typical Changes in Oxygen Consumption and in Blood lactate, Pyruvate, and pH in a Human Subject During Two Periods of Voluntary HyperVENTILATION

Ventilatory volume was increased 4.2- and 3.4-fold, respectively. There was no significant change in oxygen consumption or in brachial arterial oxygen saturation (95.7 per cent to 96.9 per cent) or pulmonary arterial saturation (70.2 per cent to 72.6 per cent) during the procedure to suggest the presence of hypoxia. Values of excess lactate for each sampling time lie on the zero line, the maximum value being $0.033 \mathrm{mM}$ per $\mathrm{L}$. 
ployed instead. It subsequently proved to be possible to give continuous intravenous infusions of pyruvate to dogs without altering blood $\mathrm{pH}$. The infusates consisted of 0.5 molar pyruvic acid buffered at $\mathrm{pH}$ between 5.0 and 6.0 When this was done, neither blood lactate nor pyruvate rose during infusions at the previous rates. However, when larger amounts were given [rates between 2 and $5 \mathrm{ml}$. per minute $(0.5$ to $2.5 \mathrm{mM}$ per minute)], the great capacity of the body to absorb pyruvate apparently could be overloaded and blood pyruvate made to rise. The experiments in which this was accomplished without change in blood $\mathrm{pH}$ are shown in Figure 2 and Table I. It was found that tissue lactate production followed the rise in body pyruvate. Rates of oxygen consumption remained constant if blood $\mathrm{pH}$ remained constant; mixed venous blood oxygen saturation did not fall. Hypoxia of the severity which might lead to these large lactate accumulations, therefore, did not appear to be present. The blood pyruvate levels fell promptly following cessation of pyruvate infusion.

Table II shows the effects of infusion of $500 \mathrm{ml}$. of 10 per cent glucose into human subjects in 30 minutes. The animals received a similar amount ( $1 \mathrm{Gm}$. per $\mathrm{Kg}$. body weight) in 30 minutes. The results are in agreement with those previously published (19); both lactate and pyruvate concentrations rose, and the ratio of the two changed only slightly.

Figure 3 and Table III show the increase in blood lactate which resulted from voluntary hyperventilation in human subjects. From the measurements of rate of oxygen consumption $\left(\mathrm{V}_{\mathrm{o}_{2}}\right)$ it is clear that no measurable reduction occurred in the rate of delivery of oxygen per minute to the tissues, and that no $\mathrm{O}_{2}$-debt was contracted. In two instances mixed venous blood was sampled from the pulmonary artery during the hyperven-

TABLE III

Effect of voluntary hyperventilation for 15 minutes in human subjects *

\begin{tabular}{|c|c|c|c|c|c|c|}
\hline Procedure & Lactate & Pyruvate & $\mathrm{XL}$ & $\mathrm{pH}$ & $\dot{v}_{02}$ & $\mathrm{~S}_{\mathrm{V}_{\mathbf{2}}}$ \\
\hline 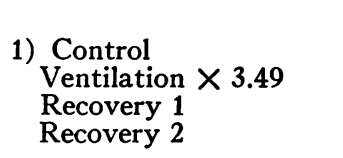 & $\begin{array}{l}m M / L \\
0.696 \\
0.999 \\
1.799 \\
0.675\end{array}$ & $\begin{array}{l}m M / L . \\
0.135 \\
0.195 \\
0.343 \\
0.130\end{array}$ & $\begin{array}{c}0 \\
0 \\
0.029 \\
0\end{array}$ & $\begin{array}{l}7.40 \\
7.47 \\
7.43 \\
7.41\end{array}$ & $\begin{array}{c}m l . / m i n . \\
252 \\
280 \\
250 \\
255\end{array}$ & $\begin{array}{l}\% \\
74 \\
77 \\
75 \\
73\end{array}$ \\
\hline $\begin{array}{l}\text { 2) Control } \\
\text { Ventilation } \times 4.60 \\
\text { Recovery } 1 \\
\text { Recovery } 2\end{array}$ & $\begin{array}{l}0.772 \\
1.241 \\
2.099 \\
0.683\end{array}$ & $\begin{array}{l}0.131 \\
0.207 \\
0.347 \\
0.116\end{array}$ & $\begin{array}{l}0 \\
0.021 \\
0.052 \\
0\end{array}$ & $\begin{array}{l}7.39 \\
7.53 \\
7.40 \\
7.40\end{array}$ & $\begin{array}{l}287 \\
316 \\
280 \\
295\end{array}$ & $\begin{array}{l}72 \\
78 \\
72 \\
74\end{array}$ \\
\hline $\begin{array}{l}\text { 3) Control } \\
\text { Ventilation } \times 3.05 \\
\text { Recovery } 1 \\
\text { Recovery } 2\end{array}$ & $\begin{array}{l}0.582 \\
0.643 \\
0.991 \\
0.570\end{array}$ & $\begin{array}{l}0.124 \\
0.137 \\
0.204 \\
0.143\end{array}$ & $\begin{array}{l}0 \\
0 \\
0.033 \\
0\end{array}$ & $\begin{array}{l}7.42 \\
7.50 \\
7.41 \\
7.40\end{array}$ & $\begin{array}{l}312 \\
327 \\
310 \\
330\end{array}$ & \\
\hline $\begin{array}{l}\text { 4) Control } \\
\text { Ventilation } \times 4.01 \\
\text { Recovery } 1 \\
\text { Recovery } 2\end{array}$ & $\begin{array}{l}0.629 \\
0.940 \\
1.877 \\
0.650\end{array}$ & $\begin{array}{l}0.125 \\
0.182 \\
0.361 \\
0.126\end{array}$ & $\begin{array}{l}0 \\
0.025 \\
0.063 \\
0.016\end{array}$ & $\begin{array}{l}7.40 \\
7.51 \\
7.42 \\
7.40\end{array}$ & $\begin{array}{l}195 \\
220 \\
200 \\
204\end{array}$ & \\
\hline $\begin{array}{l}\text { 5) Control } \\
5 \% \mathrm{CO}_{2} \text {, Vent. } \times 4.20 \\
\text { Recovery } 1 \\
\text { Recovery } 2\end{array}$ & $\begin{array}{l}0.560 \\
0.565 \\
0.559 \\
0.563\end{array}$ & $\begin{array}{l}0.132 \\
0.129 \\
0.131 \\
0.132\end{array}$ & $\begin{array}{l}0 \\
0.018 \\
0 \\
0\end{array}$ & $\begin{array}{l}7.41 \\
7.39 \\
7.41 \\
7.41\end{array}$ & $\begin{array}{l}251 \\
267 \\
242 \\
242\end{array}$ & \\
\hline $\begin{array}{l}\text { 6) Control } \\
5 \% \mathrm{CO}_{2} \text {, Vent. } \times 3.56 \\
\text { Recovery } 1 \\
\text { Recovery } 2\end{array}$ & $\begin{array}{l}0.607 \\
0.608 \\
0.620 \\
0.615\end{array}$ & $\begin{array}{l}0.142 \\
0.145 \\
0.140 \\
0.141\end{array}$ & $\begin{array}{c}0 \\
0 \\
0.021 \\
0.016\end{array}$ & $\begin{array}{l}7.40 \\
7.40 \\
7.41 \\
7.40\end{array}$ & $\begin{array}{l}275 \\
296 \\
270 \\
275\end{array}$ & \\
\hline
\end{tabular}

* Arterial blood lactate, pyruvate, $\mathrm{pH}$, oxygen consumption $\left(\dot{\mathrm{V}}_{2}\right)$ and mixed venous blood oxygen saturation $\left(\mathrm{S} \overline{\mathrm{V}}_{\mathrm{O}_{2}}\right)$ were measured, and excess lactate $(\mathrm{XL})$ calculated as described. Two additional hyperventilation periods are given in Figure 1. In Experiments 5 and 6 hyperventilation was induced with 5 per cent $\mathrm{CO}_{2}$ in 20 per cent $\mathrm{O}_{2}, 75$ per cent $\mathrm{N}_{2}$. Values marked "hyperventilation" were obtained at the end of the forced breathing period; "Recovery 1" is the peak value of pyruvate; "Recovery 2" values obtained 45 minutes after cessation of hyperventilation. 
RELATIONSHIPS OF PYRUVATE AND LACTATE IN HYPOXIA

TABLE IV

Effect of threefold increase in pump-controlled pulmonary ventilation in dogs upon blood lactate and pyruvate concentrations

\begin{tabular}{|c|c|c|c|c|c|c|}
\hline Procedure & Lactate & Pyruvate & $\mathrm{XL}^{*}$ & $\mathrm{pH}$ & $\dot{\mathrm{V}}_{\mathrm{O}_{2}}{ }^{*}$ & $\mathrm{~S}_{\mathrm{V}_{2}}{ }^{*}$ \\
\hline $\begin{array}{l}\text { 1) Control } \\
\text { Hyperventilation } \\
\text { Recovery } 1 \\
\text { Recovery } 2\end{array}$ & $\begin{array}{l}m M / L . \\
0.724 \\
2.460 \\
3.657 \\
0.680\end{array}$ & $\begin{array}{l}m M / L . \\
0.120 \\
0.402 \\
0.590 \\
0.113\end{array}$ & $\begin{array}{l}0 \\
0.032 \\
0.093 \\
0\end{array}$ & $\begin{array}{l}7.41 \\
7.67 \\
7.39 \\
7.40\end{array}$ & $\begin{array}{l}\text { ml. } / \text { min. } \\
60 \\
67 \\
62 \\
64\end{array}$ & $\begin{array}{l}\% \\
75 \\
82 \\
77 \\
75\end{array}$ \\
\hline $\begin{array}{l}\text { 2) Control } \\
\text { Hyperventilation } \\
\text { Recovery } 1 \\
\text { Recovery } 2\end{array}$ & $\begin{array}{l}0.655 \\
1.840 \\
2.789 \\
0.650\end{array}$ & $\begin{array}{l}0.129 \\
0.361 \\
0.542 \\
0.127\end{array}$ & $\begin{array}{l}0 \\
0.006 \\
0.034 \\
0.005\end{array}$ & $\begin{array}{l}7.38 \\
7.49 \\
7.40 \\
7.39\end{array}$ & $\begin{array}{r}96 \\
104 \\
93 \\
95\end{array}$ & $\begin{array}{l}74 \\
79 \\
75 \\
75\end{array}$ \\
\hline $\begin{array}{l}\text { 3) Control } \\
\text { Hyperventilation } \\
\text { Recovery } 1 \\
\text { Recovery } 2\end{array}$ & $\begin{array}{l}0.789 \\
1.092 \\
2.009 \\
0.776\end{array}$ & $\begin{array}{l}0.127 \\
0.175 \\
0.324 \\
0.125\end{array}$ & $\begin{array}{l}0 \\
0.004 \\
0.005 \\
0\end{array}$ & $\begin{array}{l}7.36 \\
7.52 \\
7.38 \\
7.36\end{array}$ & $\begin{array}{l}71 \\
79 \\
70 \\
70\end{array}$ & $\begin{array}{l}70 \\
77 \\
77 \\
72\end{array}$ \\
\hline $\begin{array}{l}\text { 4) Control } \\
\text { Hypervent.-100\% } \mathrm{O}_{2} \\
\text { Recovery 1 } \\
\text { Recovery } 2\end{array}$ & $\begin{array}{l}0.851 \\
2.052 \\
3.657 \\
0.857\end{array}$ & $\begin{array}{l}0.133 \\
0.318 \\
0.560 \\
0.133\end{array}$ & $\begin{array}{l}0 \\
0.016 \\
0.076 \\
0\end{array}$ & $\begin{array}{l}7.41 \\
7.54 \\
7.41 \\
7.41\end{array}$ & $\begin{array}{l}67 \\
74 \\
68 \\
69\end{array}$ & $\begin{array}{l}75 \\
90 \\
78 \\
76\end{array}$ \\
\hline $\begin{array}{l}\text { 5) Control } \\
\text { Hypervent.-100\% } \mathrm{O}_{2} \\
\text { Recovery } 1 \\
\text { Recovery } 2\end{array}$ & $\begin{array}{l}0.898 \\
2.751 \\
3.421 \\
0.901\end{array}$ & $\begin{array}{l}0.112 \\
0.337 \\
0.412 \\
0.111\end{array}$ & $\begin{array}{l}0 \\
0.048 \\
0.118 \\
0.011\end{array}$ & $\begin{array}{l}7.42 \\
7.59 \\
7.41 \\
7.41\end{array}$ & $\begin{array}{r}98 \\
107 \\
98 \\
96\end{array}$ & $\begin{array}{l}72 \\
89 \\
80 \\
74\end{array}$ \\
\hline 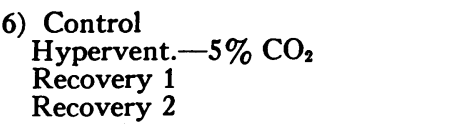 & $\begin{array}{l}0.750 \\
0.720 \\
0.729 \\
0.745\end{array}$ & $\begin{array}{l}0.139 \\
0.131 \\
0.133 \\
0.137\end{array}$ & $\begin{array}{l}0 \\
0 \\
0 \\
0\end{array}$ & $\begin{array}{l}7.38 \\
7.36 \\
7.38 \\
7.39\end{array}$ & $\begin{array}{l}82 \\
82 \\
82 \\
83\end{array}$ & $\begin{array}{l}74 \\
87 \\
80 \\
75\end{array}$ \\
\hline $\begin{array}{l}\text { 7) Control } \\
\text { Hypervent.-95\% } \mathrm{O}_{2}, 5 \% \mathrm{CO}_{2} \\
\text { Recovery } 1 \\
\text { Recovery } 2\end{array}$ & $\begin{array}{l}0.689 \\
0.605 \\
0.670 \\
0.662\end{array}$ & $\begin{array}{l}0.141 \\
0.122 \\
0.135 \\
0.133\end{array}$ & $\begin{array}{l}\mathbf{0} \\
\mathbf{0} \\
\mathbf{0} \\
\mathbf{0}\end{array}$ & $\begin{array}{l}7.42 \\
7.40 \\
7.43 \\
7.43\end{array}$ & $\begin{array}{l}109 \\
111 \\
113 \\
113\end{array}$ & $\begin{array}{l}71 \\
91 \\
80 \\
76\end{array}$ \\
\hline
\end{tabular}

* See Table I for identification of these abbreviations.

tilation; the oxygen saturations show no decrease in the mean $\mathrm{Po}_{2}$ of blood draining body tissues, and cardiac output was not diminished. Although it, therefore, seems very unlikely that hypoxia was produced by the hyperventilation, lactate production was, nevertheless, very prominent. An increase in muscular exertion occurred with voluntary hyperventilation, however, and this may account for the lactate production.

Table IV, on the other hand, shows that similar results were obtained in dogs which were passively hyperventilated by means of a respiratory pump; in each instance minute volume of respiration was increased threefold over the normal resting value by first doubling tidal volume and then adjusting the respiratory rate, during repeated collections of expired air. Again no auxiliary evidence of oxygen deficiency could be found to account for the lactate production. Indeed, improved oxygenation, as in Experiments 4 and 5, failed to prevent the lactic acidemia. If blood $\mathrm{pH}$ was prevented from rising, however, by inclusion of 5 per cent carbon dioxide in the gas mixture inspired, lactate accumulation failed to occur during the hyperventilation as shown in Experiments 6 and 7 of Table III and Experiments 6 and 7 of Table IV. The rate of lactate accumulation showed no clear quantitative relationship to the amount of rise of blood $\mathrm{pH}$ in these experiments.

The maximum value of blood pyruvate was reached in all experiments after the end of hyperventilation when normal breathing had resumed. The time of the peak varied from 8 to 28 minutes following the resumption of normal breathing, with a mean time of 14 minutes. Timing of the lactate changes was the same.

The outstanding correlation revealed in these data is that between blood concentrations of lactate and of pyruvate. The amount of change in pyruvate was, of course, quite different from that 
in lactate concentration, but the two bore a consistent straight line relationship during their alterations (in any one individual) so that the ratio changed little.

Methods of collecting, preserving and analysing blood for lactate and pyruvate have varied considerably in the past. It is difficult to rule out the possibility that the methods used have greatly affected some of the results published, and these should be considered in detail.

The present techniques have yielded the following basal concentrations in arterial blood of 69 normal human subjects : lactate, $0.618 \mathrm{mM}$ per L. blood $\mathrm{H}_{2} \mathrm{O}(\sigma=0.077)$; pyruvate, $0.142 \mathrm{mM}$ per L. blood $\mathrm{H}_{2} \mathrm{O}(\sigma=0.026)$; lactate-pyruvate ratio, $4.24(\sigma=0.44)$. These values differ considerably from those in previous reports.

\section{DISCUSSION}

Mean resting human blood pyruvate values of 0.045 to $0.085 \mathrm{mM}$ per L. (20), 0.088 (21), 0.116 (19), and 0.114 (22) have been reported. Peripheral venous blood was used, with varying degrees of care in rapidity of denaturation. Bueding and Wortis (23) believed pyruvate decreased rapidly in shed blood, changes being significant within a few seconds. We have confirmed this finding (14).

Corresponding values for blood lactate have been reported to be $1.11 \mathrm{mM}$ per L. (13), 1.45 (24), 1.54 (25), and $1.13 \mathrm{mM}$ per L. (21). After the development of the precise and highly specific analytical method of Barker and Summerson (26), mean values of $0.887 \mathrm{mM}$ per L. (27), 1.03 (22), and $0.667 \mathrm{mM}$ per L. (28) were reported.

Mean resting lactate-pyruvate ratios have been 13.4 (2), 13.2 (21), 9.3 (19), 11.3 (21), and 10.6 (28). It has been stated that the "basal state" does not give the lowest lactate-pyruvate ratio and that fairly vigorous walking produces no increase in it (19), or in lactate (13).

In the present study, using arterial blood and no lapse of time between sampling and denaturation of the blood, quite different conclusions have been arived at. Measurements by these techniques have shown arterial blood lactate and lactate-pyruvate ratio to increase immediately (in less than one minute) on the mildest exertion (29), although analysis of venous blood does not reveal this change. Our data on the resting state indicate that bed rest and the nearest possible approach to basal conditions yields the lowest body lactate and lactate-pyruvate ratio, and these minimal reference values are much lower than previously reported. Lactate, pyruvate, and the lactate-pyruvate ratio always fell during the resting control periods of one and one-half to two and one-half hours, and a plateau was usually reached in one hour. The average fall in lactate concentration in 32 human subjects was $0.320 \mathrm{mM}$ per $\mathrm{L} . \mathrm{H}_{2} \mathrm{O}$, of pyruvate, $0.021 \mathrm{mM}$ per L., and of the lactatepyruvate ratio, 2.60 .

It has been shown that any delay in the denaturation of blood causes much lower pyruvate and somewhat higher lactate concentrations, with very significantly higher ratios of lactate to pyruvate than appear to exist in the body (14). We have found that fluoride significantly accelerates the immediate disappearance of pyruvate from shed blood and the rise of the lactate-pyruvate ratio. Iodoacetate produces a rise in blood pyruvate with time in vitro and, therefore, an artifactual depression of the lactate-pyruvate ratio. The greatest difference in results, however, is produced by the use of peripheral venous blood, an error which has been pointed out previously $(30-32)$. It must be recognized that these values may reflect purely local events in the limb as much as they reflect changes in total body lactate and pyruvate. During changing levels the error may be 100 per cent or more. In 15 of our normal basal subjects, blood drawn from a vein by the method of Friedemann, Haugen, and Kmieciak (21) gave a mean lactate concentration of $1.222 \mathrm{mM}$ per $\mathrm{L}$. blood $\mathrm{H}_{2} \mathrm{O}(\sigma=$ $0.354)$, as compared with a simultaneous value of $0.643(\sigma=0.079)$ by the present method, and a mean pyruvate concentration of $0.119 \mathrm{mM}$ per L. $(\sigma=0.049)$, as compared with $0.146(\sigma=0.026)$.

The present data were obtained with these technical improvements and appear to demonstrate a rather marked lactate production in the body in response to slight changes in body $\mathrm{pH}$, glucose and pyruvate in the complete absence of oxygen lack. They also suggest the mechanism for this occurrence, as outlined in the introduction. One of the two factors affecting the body lactate content is the tissue oxygen deficiency factor; the other, however, is pyruvate concentration, which may change considerably in the absence of any oxygen 
lack, as illustrated in the present data. This is demonstrated most simply by changing pyruvate artificially by infusing this substance. One of the most potent gross stimuli to endogenous pyruvate production in the intact body, however, appears to be a change in acid-base balance. Since pyruvate levels are the resultant of a great number of different chemical equilibria in the body, it is not possible to quantitate the various causes for pyruvate change during hypocapnia. Whatever may be the detailed reasons, when pyruvate does change it is possible to predict from equation 2) that lactate will change also, and that it will change by an amount which can be derived from the equation (if hypoxia is absent). Equation 2), of course, states that the ratio of lactate to pyruvate should remain constant during the interval under study if hypoxia is absent. Some change in the lactatepyruvate ratio did occur in the present experiments, although it seems very small.

Only if no change in the lactate-pyruvate ratio had occurred could the significance mentioned be assigned to this observation. If some change did occur, it would then be impossible to know in any real terms how significant this might be. One could only say, in that case, that the equilibrium of equation 1) was being displaced to the right to some unknown extent. The total rate of this shift might be very great for even such a small distortion of the lactate-pyruvate ratio as seen in the present experiments, or it might be negligible. Rates of change of "excess lactate" concentrations in all the experiments reported here, when multiplied by the volume of total body water and by a factor of 11.2 to convert millimoles to oxygen equivalents (29), constitute less than 0.1 per cent of the rate of oxygen consumption. This appears to be negligible, and the essential constancy of $\mathrm{K} \frac{\left[\mathrm{DPNH}_{2}\right]}{[\mathrm{DPN}]}$ in the present experiments is reliably confirmed. Under other conditions the "excess lactate" has proved to be of very significant proportions relative to oxygen consumption, but this situation is physiologically quite different and is dealt with separately (29).

The constancy of these relationships in the present experiments has some important implications with respect to metabolic studies generally in man and intact animals, when blood analysis must be employed. The lactic dehydrogenase system lies within the cells, but concentrations were measured in these subjects in the blood. In the alkalinization experiments, therefore, the arterial blood lactate concentrations appear to have changed in a manner which accurately reflected the mean of theoretical intracellular changes in the body as calculated above. Passive diffusion across cell membranes (although not identical concentrations in intracellular and extracellular fluids) has previously been proposed for these ions $(14,33)$. In the pyruvate infusion experiments, moreover, the primary pyruvate change occurred in the blood and must have effected secondarily a change within the cells which then altered lactate concentration, first intracellularly and subsequently in the blood. Despite this double transit across cell membranes, blood lactate still followed blood pyruvate rather faithfully. ${ }^{3}$ Such small amounts of calculated "excess lactate" as were present may represent lags in diffusion equilibration.

Lactate production theoretically is not controlled exclusively by the adequacy of cellular oxygenation, and is demonstrably affected to a very significant extent by the pyruvate changes of overventilation or $\mathrm{pH}$ alterations of the body, of blood glucose changes and probably other stimuli. It would, therefore, seem quite inadvisable to draw any conclusions about tissue oxygen supply from determinations of lactate alone. Hyperventilation in human subjects has previously been noted to be associated with lactic acidemia $(13,17)$, but muscular exertion also occurred, and no clear explanation for the finding was apparent. Similar effects of $\mathrm{pH}$ on tissue lactate production may be deduced from data reported in the heart-lung preparation (34) in isolated limb preparations (35), and in intact dogs $(18,36)$. Our findings augment these data and suggest that the changes in lactate may be interpreted as responses to pyruvate accumulation.

The $\mathrm{pH}$ effect, however, is only one of several general conditions leading to lactate accumulation without hypoxia. Himwich (10) reviewed the effect of administering various carbohydrates in

\footnotetext{
${ }^{3}$ Even in pieces of excised tissue, devoid of circulation altogether, a double transit path in the same sense appears to lead to only about 15 per cent difference in specific activity of lactate and isotope-tagged pyruvate in the incubation medium (4) and close parallelism during changing activity (5).
} 
producing lactic acidemia. Rises in blood lactate in human subjects due to glucose administration have been studied more recently by Bueding, Stein, Wortis, and Goldfarb $(11,16)$ and many others. The work cited likewise demonstrated a pyruvic acid accumulation of corresponding magnitude resulting from glucose injection.

Epinephrine causes increased lactate production by muscle (10) which is not due to diminished blood flow (37) or altered arteriovenous oxygen difference (38), and produces lactate accumulation (12). Again, pyruvate accumulation is known to occur as a result of epinephrine injection (39).

In view of the significant changes in carbohydrate metabolism resulting from $\mathrm{pH}$ change (40, 41 ), it appears possible as an interrelation of the diverse events listed above that all the stimuli mentioned produce pyruvate accumulation through effects on the processes of carbohydrate metabolism which they have in common.

However this may be, it is suggested from the present studies that lactate accumulation ensues as a result of its tendency to maintain equilibrium with the pyruvate present, and the equations derived for this relationship appear to suggest that experimental lactate changes fit the concept satisfactorily. With further investigation such a concept might help to clarify the complex relationship between tissue oxygen deficiency and lactic acid production.

Considering the rapidity with which lactic acid accumulation may be brought about, this phenomenon observed during hyperventilation represents a mechanism for quickly reducing body bicarbonate as an adjustment to alkalosis. We have seen several human subjects with pathological hyperventilation who replaced half or more of their serum bicarbonate with lactate in the course of several hours. Considering the fact that 10 to 12 $\mathrm{mM}$ per L. of lactic acid may at times be found to accumulate within a few minutes, this mechanism of acid-base homeostasis can have almost as great rapidity of response as carbon dioxide tension itself. If a patient's primary derangement is respiratory alkalosis, the $\mathrm{LDH}$ mechanism of tissue acid production would appear to be the only immediate compensatory response available.

\section{SUMMARY AND CONCLUSIONS}

1. Small and large accumulations of lactate were produced in human subjects and animals by methods which would not be expected to induce hypoxia: hyperventilation and infusion of bicarbonate, pyruvate or glucose. Arterial and mixed venous blood oxygen saturations and rates of oxygen consumption gave no indication that any detectable hypoxia was induced by the procedures.

2. Simultaneous accumulations of pyruvate occurred in each instance.

3. The lactate changes were found to correspond closely to those of pyruvate according to equations derived for steady state of the lactic dehydrogenase system and absence of hypoxia.

4. It is concluded that production of lactate by tissues in intact man and animals has no necessary significance with respect to hypoxia of the tissues.

5. A calculated fraction of any total lactate change ("excess lactate") is theoretically not subject to the error of nonhypoxic production and appears experimentally to be essentially zero throughout wide fluctuations of total lactate induced by nonhypoxic stimuli.

6. The data suggest that changes in blood concentrations of pyruvate and lactate in intact man and animals, when estimated by the methods described, closely approximate those occurring at the loci of the enzyme lactic dehydrogenase, i.e., within tissue cells.

\section{APPENDIX}

The lactic dehydrogenase system may be depicted by:

1) $\mathrm{C}_{3} \mathrm{H}_{4} \mathrm{O}_{3}+\mathrm{DPNHH}^{+} \rightleftarrows \mathrm{C}_{3} \mathrm{H}_{5} \mathrm{O}_{3}+\mathrm{DPN}$

or by the mass action form:

2) $[$ Pyruvate $] \times\left[\mathrm{DPNHH}^{+}\right]=\mathrm{K}[$ Lactate $] \times[\mathrm{DPN}]$ which may be rearranged to show the two physiologic factors affecting lactate concentration at any time $t_{0}$ :

3) $[\text { Lactate }]_{0}=[\text { Pyruvate }]_{0} \times \mathrm{K} \frac{\left[\mathrm{DPNH}{ }^{+} \mathrm{H}\right]_{0}}{[\mathrm{DPN}]_{0}}$

The difference in lactate between $t_{o}$ and any other time $t_{n}$, provided there is no hypoxia, will be:

4) $[\text { Lactate }]_{n}-[\text { Lactate }]_{0}=[\text { Pyruvate }]_{n}$

$$
-[\text { Pyruvate }]_{0} \times \mathrm{K} \frac{[\mathrm{DPNH}]_{0}}{[\mathrm{DPN}]_{0}}
$$

Substituting from equation 3 ) the value obtained by solving for $\mathrm{K} \frac{[\mathrm{DPNH}]_{0}}{[\mathrm{DPN}]_{0}}$ :

5) $[\text { Lactate }]_{n}-[\text { Lactate }]_{0}=[\text { Pyruvate }]_{n}$

$$
-[\text { Pyruvate }]_{0} \times \frac{[\text { Lactate }]_{0}}{[\text { Pyruvate }]_{0}}
$$

The difference between the value of $\hat{L}_{n}-\hat{L}_{0}$, predicted from equation 5 ) on the assumption that no true hypoxia 
occurred within the cells, and the value of $L_{n}-L_{0}$ actually observed to occur is the "excess lactate:"

6)

$$
\mathrm{XL}=\Delta \mathrm{L}-\widehat{\Delta \mathrm{L}}
$$

and in terms of measurable quantities (all concentrations):

7) $\quad \mathrm{XL}=\left(\mathrm{L}_{n}-\mathrm{L}_{\mathrm{o}}\right)-\left(\mathrm{P}_{\mathrm{n}}-\mathrm{P}_{\mathrm{o}}\right)\left(\mathrm{L}_{\mathrm{o}} / \mathrm{P}_{\mathrm{o}}\right)$

A sample calculation gives the following result:

Basal blood lactate $=0.550 \mathrm{mM}$ per $\mathrm{L}$.

Basal blood pyruvate $=0.135 \mathrm{mM}$ per $\mathrm{L}$.

Experimental lactate value $=2.680 \mathrm{mM}$ per $\mathrm{L}$.

Experimental pyruvate value $=0.409 \mathrm{mM}$ per $\mathrm{L}$.

$$
\begin{aligned}
\mathrm{XL} & =(2.680-0.550)-(0.409-0.135)\left(\frac{0.550}{0.135}\right) \\
& =2.130-1.115 \\
\mathrm{XL} & =1.015 \mathrm{mM} \text { per } \mathrm{L} .
\end{aligned}
$$

\section{REFERENCES}

1. Hewitt, L. F. Oxidation-reduction potentials in Bacteriology and Biochemistry, 6th ed. Baltimore, Williams and Wilkins Co., 1950, pp. 95-126.

2. Baumberger, J. P. The relation between the "oxidation-reduction potential" and the oxygen consumption rate of yeast cell suspensions. Cold Spr. Harb. Symp. quant. Biol. 1939, 7, 195.

3. Stotz, E. Pyruvate metabolism. Advanc. Enzymol. 1945, 5, 129.

4. Teng, C., Karnovsky, M. L., Landau, B. R., Hastings, A. B., and Nesbett, F. B. Metabolism of $\mathrm{C}^{\mathbf{1 4}}$-labeled glycerol and pyruvate by liver in vitro. J. biol. Chem. 1953, 202, 705.

5. Foster, J. M., and Villee, C. A. Pyruvate and acetate metabolism in the isolated rat diaphragm. J. biol. Chem. 1954, 211, 797.

6. Araki, T. Ueber die Bildung von Milchsäure und Glycose im Organismus bei Sauerstoffmangel. Hoppe-Seylers Z. physiol. Chem. 1890, 15, 335.

7. Hastings, A. B. The lactic acid in the blood of dogs in exercise. Proc. Soc. exp. Biol. (N. Y.) 1920 1921, 18, 306.

8. Hill, A. V., Long, C. N. H., and Lupton, H. Muscular exercise, lactic acid and the supply and utilization of oxygen. V. The recovery process after exercise in man. Proc. roy. Soc. B. 1924, 97, 96.

9. Jervell, $O$. Investigation of the concentration of lactic acid in blood and urine under physiologic and pathologic conditions. Acta. med scand. 1928, Suppl. 24, 1.

10. Himwich, H. E. The role of lactic acid in the living organism. Yale J. Biol. Med. 1931-1932, 4, 259.

11. Bueding, E., Stein, M. H., and Wortis, H. Blood pyruvate curves following glucose ingestion in normal and thiamine-deficient subjects. J. biol. Chem. 1941, 140, 697.

12. Cori, C. F., and Cori, G. T. Mechanism of epinephrine action. IV. The influence of epinephrine on lactic acid production and blood sugar utilization. J. biol. Chem. 1929, 84, 683.
13. Bock, A. V., Dill, D. B., and Edwards, H. T. Lactic acid in the blood of resting man. J. clin. Invest. 1932, 11, 775.

14. Huckabee, W. E. Control of concentration gradients of pyruvate and lactate across cell membranes in blood. J. appl. Physiol. 1956, 9, 163.

15. Huckabee, W. E. Spectrophotometric analysis of uncontaminated blood for oxyhemoglobin. J. Lab. clin. Med. 1955, 46, 486.

16. Bueding, E., and Goldfarb, W. J. Blood changes following glucose, lactate, and pyruvate injections in man. J. biol. Chem. 1943, 147, 33.

17. Fenn, W. O., Rahn, H., Otis, A. B., and Chadwick, L. E. Physiological observations on hyperventilation at altitude with intermittent pressure breathing by the pneumolator. J. appl. Physiol. 1948, 1, 773.

18. Haldi, J. Lactic acid in blood and tissues following intravenous injection of sodium bicarbonate. Amer. J. Physiol. 1933, 106, 134.

19. Bueding, E., Wortis, H., and Stern, M. Pathological variations in blood and spinal fluid pyruvic acid. J. clin. Invest. 1942, 21, 85.

20. Platt, B. S., and Lu, G. D. Studies on the metabolism of pyruvic acid in normal and vitamin $B_{1}$-deficient states. IV. The accumulation of pyruvic acid and other carbonyl compounds in beri-beri and the effect of vitamin $B_{1}$. Biochem. J. 1939, 33, 1525.

21. Friedemann, T. E., Haugen, G. E., and Kmieciak, T. C. Pyruvic acid. III. The level of pyruvic and lactic acids, and the lactic-pyruvate ratio, in the blood of human subjects. The effect of food, light muscular activity and anoxia at high altitude. J. biol. Chem. 1945, 157, 673.

22. Goldsmith, G. A. The blood lactate-pyruvate relationship in various physiologic and pathologic states. Amer. J. med. Sci. 1948, 215, 182.

23. Bueding, E., and Wortis, $H$. The stabilization and determination of pyruvic acid in the blood. $\mathrm{J}$. biol. Chem. 1940, 133, 585.

24. Weiss, S., and Ellis, L. B. Oxygen utilization and lactic acid production in the extremities during rest and exercise. Arch. intern. Med. 1935, 55, 665.

25. Hallock, $P$. Lactic acid production during rest and after exercise in subjects with various types of heart disease with special reference to congenital heart disease. J. clin. Invest. 1939, 18, 385.

26. Barker, S. B., and Summerson, W. H. The colorimetric determination of lactic acid in biological material. J. biol. Chem. 1941, 138, 535.

27. Decker, D. G., and Rosenbaum, J. D. The distribution of lactic acid in human blood. Amer. J. Physiol. 1942, 138, 7.

28. Bay, E., Barron, E. S. G., Adams, W., Case, T., Halstead, W. C., and Ricketts, H. T. The behavior of blood lactate and pyruvate with exercise at sea-level and at altitude. Part III. National Research Council Report No. 344, Committee on Aviation Medicine, 1944. 
29. Huckabee, W. E. Relationships of pyruvate and lactate during anaerobic metabolism. II. Exercise and formation of $\mathrm{O}_{2}$-debt. $\mathrm{J}$. clin. Invest. 1958, 37, 255.

30. Himwich, H. E., Loebel, R. O., and Barr, D. P. Studies of the effect of exercise in diabetes. I. Changes in acid-base equilibrium and their relation to the accumulation of lactic acid and acetone. J. biol. Chem. 1924, 59, 265.

31. Barr, D. P., and Himwich, H. E. Studies in the physiology of muscular exercise. II. Comparison of arterial and venous blood following vigorous exercise. J. biol. Chem. 1923, 55, 525.

32. Eggleton, M. G., and Evans, C. L. The lactic acid content of blood after muscular contraction under experimental conditions. J. Physiol. 1930, 70, 269.

33. Newman, E. V. Distribution of lactic acid between blood and muscle of rats. Amer. J. Physiol. 1938, 122, 359.

34. Anrep, C. V., and Cannan, R. K. The concentration of lactic acid in the blood and in experimental alkalaemia and acidaemia. J. Physiol. 1923, 58, 244.

35. Eggleton, M. G., and Evans, C. L. Lactic acid formation and removal with change of blood reaction. J. Physiol. 1930, 70, 261.
36. Gesell, R., Krueger, H., Gorham, G., and Bernthal, $T$. The regulation of respiration; a study of the correlation of numerous factors of respiratory control following administration of hydrochloric acid, of carbon dioxide, and the simultaneous administration of $\mathrm{CO}_{2}$ and sodium bicarbonate. Amer. J. Physiol. 1930, 94, 402.

37. Cori, C. F., Fisher, R. E., and Cori, G. T. The effect of epinephrine on arterial and venous plasma sugar and blood flow in dogs and cats. Amer. J. Physiol. 1935, 114, 53.

38. Griffith, F. R., Jr., Omachi, A., Lockwood, J. E., and Loomis, T. A. The effect of intravenous adrenalin on blood flow, sugar retention, lactate output and respiratory metabolism of peripheral (leg) tissues in the anesthetized cat. Amer. J. Physiol. 1947, 149, 64 .

39. Flock, E., Bollman, J. L., and Mann, F. C. Utilization of pyruvic acid by the dog. J. biol. Chem. 1938, $125,49$.

40. Haldane, J. B. S., Wigglesworth, V. B., and Woodrow, C. E. The effect of reaction changes on human carbohydrate and oxygen metabolism. Proc. roy. Soc. B. 1924, 96, 15.

41. Guest, M. M., and Rawson, R. A. Carbohydrate storage and mobilization with changes in blood pH. J. biol. Chem. 1941, 139, 535. 